\title{
International Monetary Reform
}

n the weekend of August 26-27, monetary officials of the world's major countries reached preliminary agreement on a plan which would provide for a supplement to existing world reserve assets. The agreement, reached in London by the Group of Ten, ${ }^{1}$ represented the result of four years of discussions and has been hailed by some as the major development in international finance during the last two decades. While it is probably too early to judge the long-range significance of the proposal, it would be useful to understand why it was made and to review some of its major details.

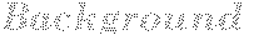

Since 1958 the volume of world trade has risen substantially. World imports, which were $\$ 100.4$ billion in 1958 , rose to $\$ 191.9$ billion in 1966, an increase of 91 per cent. ${ }^{2}$ In addition, with the return to currency convertibility by most Western European countries in late 1958 and with less likelihood of foreign investment being blocked by exchange controls, it has become more widely feasible to move private funds internationally. These capital transfers are motivated by interest rate differentials between countries and by expectations concerning the strength or weakness of individual currencies.

As a result of the growth in world trade, the mobility of short-term private capital, and the attractiveness of long-term capital investments abroad, sizable imbalances may develop more easily in a country's overall balance of payments. The imbalances may be relatively brief and the result of normal lags between receipts and expenditures. On the other hand, they may sometimes be prolonged.

1 The Group of Ten includes: Belgium, Canada, France, Germany, Italy, Japan, the Netherlands, Sweden, the United Kingdom, and the United States.

2 International Monetary Fund, International Financial Statistics, August, 1967.
By transferring international reserves, ${ }^{3}$ a country may finance a temporary balance-of-payments deficit without resorting to trade restrictions or deflationary domestic policies designed to immediately correct the deficit. International reserves, therefore, serve much the same function for a nation as cash balances serve for an individual. By varying his holdings of cash, an individual can adjust for discrepancies between the timing of his receipts (income) and his expenditures. As income and expenditures increase, the desired amount of money balances to meet these "transactions" also tends to rise. The same is true of a nation. As trade and capital movements rise, the potential discrepancies between international receipts and expenditures increase, leading to an increase in the desired stock of international reserves.

In contrast to world trade, the total stock of international reserves held by Western countries has in-

\footnotetext{
3 International reserves include; gold, convertible currencies (including the U.S. dollar), and automatic drawing rights on
} the International Monetary Fund.

Total World Trade and Monetary Reserves

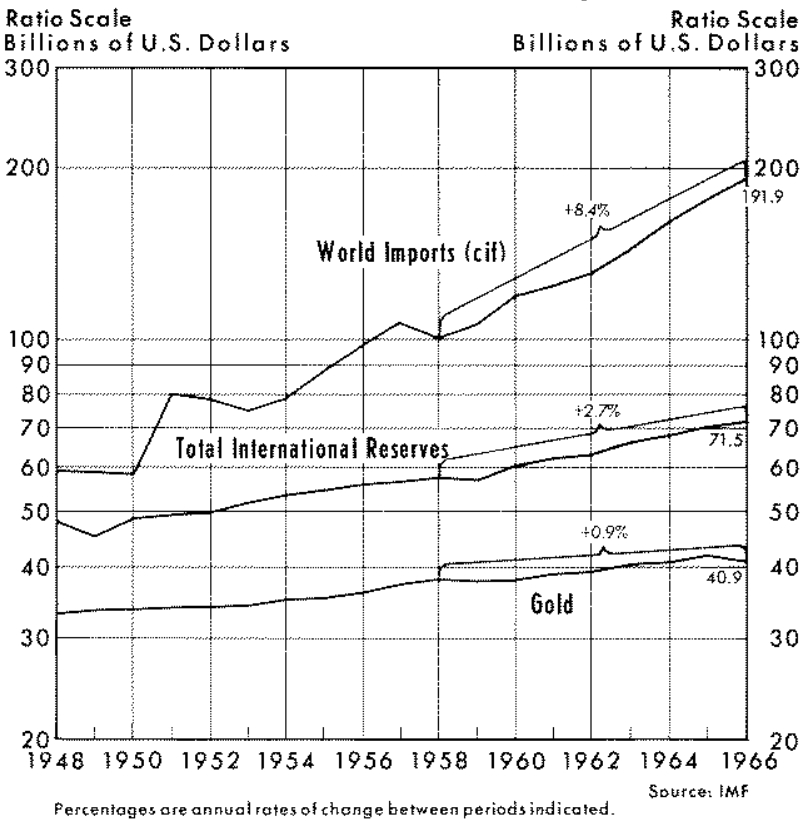


creased only moderately since 1958. Gold production has failed to expand monetary reserves significantly, and in 1966 and early 1967 hoarding and industrial uses actually decreased the free world stock of monetary gold. A major share of the growth in world reserves over the last eight years has been accounted for by the dollar." By running balanceof-payments deficits, the United States has contributed to world liquidity in the form of short-term dollar liabilities to foreigners. However, in the process, the ratio of United States short-term liabilities to its own stock of international reserves has increased. Carried far enough this might undermine confidence in the dollar as a reserve asset and result in the conversion of dollars to gold by foreign monetary authorities.

Given the United States' determination to reach an equilibrium in its balance of payments, the dollar cannot be counted upon to supply liquidity at a rate commensurate with future world needs. Since gold and other convertible currencies are not expected to appreciably increase world liquidity, many believe existing international reserves must eventually be supplemented if trade and capital movements are not to be stifled. The agreement reached in London is an initial step in this direction.

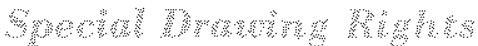

The preliminary proposal adopted by the Group of Ten calls for the creation of a supplementary reserve asset in the form of book entries in a Special Drawing Account of the International Monetary Fund (I.M.F.). The entries would be called "special drawing rights" or simply SDR, and would be denominated in units of account equivalent to the gold value of one dollar. Indications are that from $\$ 1$ to $\$ 2$ billion per year would be created in the form of SDR during an initial five-year period.

The new Special Drawing Account would be divided among the Fund's 106 member countries in accordance with their present IMF quotas. For instance, assuming that $\$ 2$ billion per year is created, the United States, whose IMF quota is currently 24.6 per cent, would

\footnotetext{
4 Since 1964 the dollar contribution to world liquidity has been negative. The growth in international reserves since then has been chielly the result of increased holdings of other convertible currencies and to increased automatic drawing rights on the Intemational Monetary Fund.
}

\section{THERHATIONAL RESERVE ASSETS \\ Wilions of U.s. bollors \\ Reserves: \\ Chonge in Reserves

\begin{tabular}{|c|c|c|c|c|c|}
\hline 1988 & 1964 & 1986 & 1958.68 & 1958.64 & 1064.66 \\
\hline 88000 & 40,645 & 40,005 & 2,875 & 2,815 & 60 \\
\hline 9.648 & 15,771 & 14,898 & 5,250 & 6,123 & 673 \\
\hline 7,317 & 7,639 & 9,382 & 2,065 & 322 & 1743 \\
\hline 2,55 & 4153 & 8,331 & 374 & 1,588 & 2,176 \\
\hline 67.552 & 688110 & 71,516 & 13964 & 100588 & 3106 \\
\hline
\end{tabular}

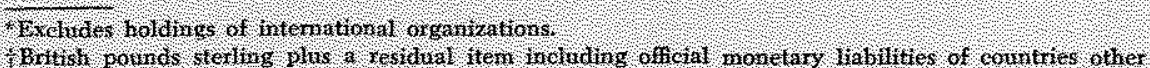
Hond

receive $\$ 492$ million per year in the form of $\mathrm{SDR}$. The United States could then draw on the account to settle balance-of-payments deficits.

Countries would not be required to pay their own currency in exchange for SDR allocations from the Fund. Instead, each would be required to accept SDR balances in exchange for convertible currency from any country tendering them to settle balance-of-payments obligations.

To insure that no individual country accumulated a disproportionate share of its total reserves in the form of special drawing rights, a limit would be placed on the volume of SDR which a country was obligated to accept. No nation would be required to accept SDR in excess of its cumulative allocation plus two times its cumulative allocation. For example, if Germany received $\$ 500$ million in SDR over a five-year period, it would be obligated to hold up to $\$ 1,500$ million in SDR balances. Thus, Germany would be required to accept at least $\$ 1,000$ million in SDR from countries who experienced balance-of-payments difficulties.

The asset would be attractive in the sense that it would yield a moderate interest return. A country might desire, therefore, to hold a volume of SDR in excess of the limit amount.

Special drawing rights would be used for balanceof-payments needs and to protect reserve positions. No country would be expected to use SDR merely to acquire other forms of reserve assets in order to alter the composition of its total stock of reserves. An eligible user could direct the Fund to transfer its SDR to a particular country for the purpose of purchasing its own currency, but only if the other country agreed to accept the SDR. This provision is of particular interest to the United States. Normally, the United States uses reserve assets to purchase foreign-held dollar balances. The special drawing rights could, therefore, be used in much the same way as the United States uses existing reserve assets. 
The main issue during the meetings in London concerned the question of whether, and on what basis, each country might need to reconstitute its cumulative SDR allocation. Some favored a provision requiring deficit countries who drew on their SDR account eventually to restore the balance. This would make SDR a form of intermediate-term credit and, as such, not much more than an extension of current IMF credit facilities. The United States, on the other hand, stressed the need for a permanent addition to world reserves which would circulate among countries without the need for repayment.

The result was a provision calling for reconstitution of SDR based on the amount and duration of its use. ${ }^{5}$ The average use of special drawing rights by a member country over a five-year period should not exceed 70 per cent of that country's average net cumulative allocation over the same period. A country would be perfectly free to use in excess of the 70 per cent figure, but would be obligated to rebuild the account to an average balance of 30 per cent by the end of the fiveyear period. The participants would be encouraged to "maintain a balanced relationship over time between their holdings of special drawing rights and other forms of reserve assets."

\footnotetext{
${ }^{5}$ For a more detailed explanation of the reconstitution provision, see: International Monetary Fund, Press Release No. 625, September 11, 1967.

6 Ibid., 5.
}

In order to call the SDR accounts into existence, an 85 per cent weighted vote would be required by the Fund's Board of Governors representing the member countries. Since the Common Market countries ${ }^{7}$, voting as a block, control 16.8 per cent of the IMF vote, they would have the power to veto a proposal to activate the accounts. The United States would likewise have veto power, since it controls in excess of 20 per cent of the Fund's total vote.

On September 29, the 106 members of the International Monetary Fund unanimously approved the plan at the Fund's meeting in Rio de Janeiro. It must now be translated into legal terms as an amendment to the articles of the IMF and ratified by the governments of at least three-fifths of the members having four-fifths of the voting power. The Managing Director of the Fund, in consultation with the Executive Board, would then have the power to propose that the SDR accounts be activated. He would suggest the date of implementation, the amount of SDR to be created, and the length of the initial period in which the accounts would be operative. The proposal would then require the 85 per cent weighted vote by the Fund's Governors. As a result of these various legislative requirements, it seems unlikely that the new plan could be called into operation before 1969 at the earliest. TThe Common Market countries include: France, Germany,
Italy, the Netherlands, Belgium, and Luxembourg. 